\title{
A review of heat recovery possibility in flue gases discharge system of gas radiant heaters
}

\author{
Edyta Dudkiewicz ${ }^{1, *}$, and Pawet Szałański ${ }^{1}$ \\ ${ }^{1}$ Department of Air Conditioning, Heating, Gas Engineering and Air Protection, Faculty of \\ Environmental Engineering, Wrocław University of Science and Technology, Wybrzeże \\ Wyspiańskiego 25, 50-373 Wrocław, Poland
}

\begin{abstract}
Heating of large-cubage buildings accounts for significant share of energy consumption. The radiant heating system using gas heaters is a common solution for large-cubage halls and is considered to be energy efficient. There is a possibility of additional heat energy recovery from the flue gases of gas radiant heaters because new solutions were introduced to the market. Furthermore heat recovery consists the most promising solution and develop during the recent years rapidly. On the other hand, few works have been dedicated to heat recovery from exhaust gas but none of them consider exhaust gas from radiant heaters. Exhaust gas temperature depends on the type and efficiency of the gas heater. The selection of both the type of radiant heaters and the heat recovery system requires many factors to be taken into account. This study consider possibilities for application of different heat exchangers in exhaust gases system of gas radiant heaters. The authors propose to classify exhaust gas heat recovery systems in dependence on intermediary medium: water/air, gas heaters type: ceramic/tube and number (single/group) and their mounting location.
\end{abstract}

\section{Introduction}

Non-residential buildings are intensive consumers of heat energy need for various purposes: heating, hot water preparation, ventilation, cooling (totally 37\%), lighting (32\%), and electric devices (24\%) [1]. Following the Fig. 1 the large-cubage buildings belong to the group in which the level of energy consumption is significant and reaches about $400 \mathrm{kWh} /\left(\mathrm{m}^{2}\right.$.year $)$. There are over 10 million $\mathrm{m}^{2}$ of industrial and logistic surface available in Poland, and another $750.000 \mathrm{~m}^{2}$ is under construction. Poland is the largest investment market in Central Europe since 2015 [2, 3]. Industrial and logistic spaces in the most industrial regions of the country are rented for about $2.50-3.90 € / \mathrm{m}^{2}$ per month. The most expensive space rental is in Warsaw, where the fee is at the level of $4-5.5 € / \mathrm{m}^{2}$ per month [2]. High investment and operating costs in large-size buildings make the business sector more and more demanding with regard to the construction and maintenance of the facilities. Furthermore, the improving of energy efficiency is required due to EU ecological policies forcing implementation of the new technologies and solutions in new project. The

*Corresponding author: edyta.dudkiewicz@pwr.edu.pl 
regulations on energy efficiency of buildings, introduced in stages in Poland, force investors to use building envelope with high thermal insulation, heat energy recovery, renewable energy sources and combined heat and power generation [4]. Many already carried out analyses show that meeting the requirements of Technical Requirements (Journal of Laws of 2015, position 1422) with the use of conventional solutions, despite significant investment costs, may be very difficult, and sometimes even impossible.

The presented study aims at addressing the following aspects: (1) determination of the maximum allowable primary energy demand in the large-cubage buildings on the basis of regulatory requirements, (2) discussion of methods of heating large-cubage halls with particular consideration of gas heaters and their parameters, (3) discussion, comparison and classification of flue gas heat recovery systems for radiant heaters.

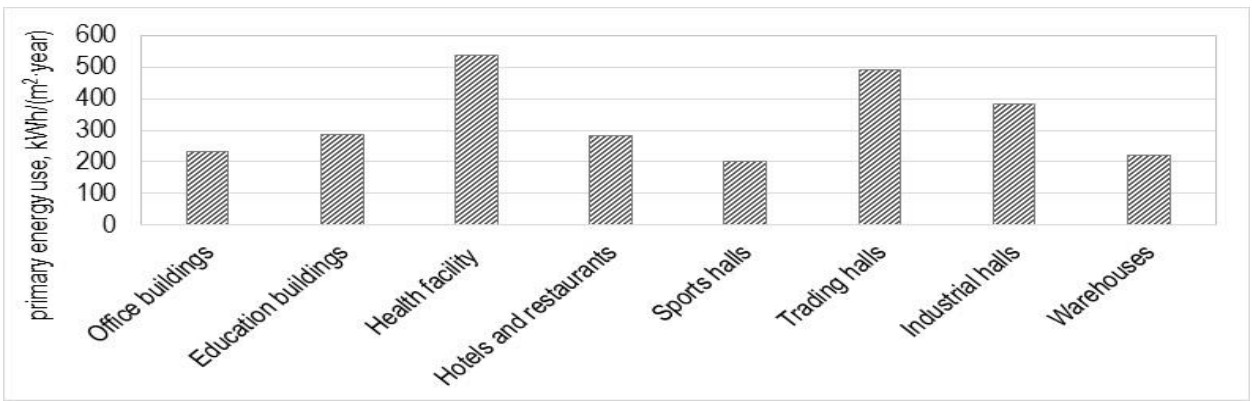

Fig. 1. The primary energy use in various kinds of non-residential buildings in Poland [1].

\section{Heating of large-cube buildings}

\subsection{Technical requirements}

The revision of the Technical Requirements (TR) for buildings in terms of energy efficiency and thermal insulation introduces a progressive increase of the requirements. The first changes shall apply from 1 January 2014, then from 1 January 2017 and from 31 December 2020. In the TR, the maximum primary energy demand index EP $\left[\mathrm{kWh} / \mathrm{m}^{2} \cdot \mathrm{a}\right]$ for heating, ventilation and domestic hot water $\left(\mathrm{EP}_{\mathrm{H}+\mathrm{W}}\right)$, cooling $\left(\mathrm{EP}_{\mathrm{C}}\right)$ and with the exception of residential buildings, also for lighting $\left(\mathrm{EP}_{\mathrm{L}}\right)$ is determined. The annual indexes for the primary energy demand EP for utility, storage, production and public buildings are given in Table 1. According to Polish regulations, calculation of the EP index is required at the stage of building design, when the energy performance is being calculated and for an existing building for the preparation of an energy performance certificate. The regulation does not apply to unheated buildings.

Table 1. Partial maximum values of EP, $\mathrm{kWh} / \mathrm{m}^{2} \cdot \mathrm{a}$.

\begin{tabular}{|c|c|c|c|c|c|c|}
\hline & \multicolumn{3}{|c|}{ from 1 January 2017} & \multicolumn{3}{|c|}{ from 1 January 2021} \\
\hline & $\mathbf{E P}_{\mathbf{H}+\mathrm{W}}$ & $\mathbf{E P}_{\mathbf{C}}$ & $\mathbf{E P}_{\mathbf{L}}$ & $\mathbf{E P}_{\mathrm{H}+\mathrm{W}}$ & $\mathbf{E P}_{\mathbf{C}}$ & $\mathbf{E P}_{\mathbf{L}}$ \\
\hline $\begin{array}{c}\text { Public } \\
\text { buildings }\end{array}$ & 60 & & $\begin{array}{c}\text { For } \\
\text { to }_{0}<2500\end{array}$ & 45 & & $\begin{array}{c}\text { For } \\
t_{0}<2500\end{array}$ \\
\hline $\begin{array}{c}\text { Store, } \\
\text { warehouse, } \\
\text { production } \\
\text { building }\end{array}$ & 90 & $\begin{array}{c}\Delta \mathrm{EPC}_{\mathrm{C}} \\
=25 \mathrm{~A}_{\mathrm{f}, \mathrm{C}} / \mathrm{A}_{\mathrm{f}}\end{array}$ & $\begin{array}{c}\Delta \mathrm{EP}_{\mathrm{L}}=50 \\
\text { For } \\
\text { to }_{\mathrm{O}}>2500 \\
\Delta \mathrm{EP}_{\mathrm{L}}=100\end{array}$ & 70 & $\begin{array}{c}\Delta \mathrm{EPC}_{\mathrm{C}}= \\
25 \mathrm{~A}_{\mathrm{f}, \mathrm{C}} / \mathrm{A}_{\mathrm{f}}\end{array}$ & $\begin{array}{c}\Delta \mathrm{EP}_{\mathrm{L}}=25 \\
\text { For } \\
\text { to }_{\mathrm{O}}>2500 \\
\Delta \mathrm{EP}_{\mathrm{L}}=50\end{array}$ \\
\hline
\end{tabular}




\subsection{Heating systems in large-cubage halls}

Aware of rising energy prices, investors of large-cubage halls have increasing expectations about the heating system. They expect rational low investment, operation and maintenance costs, ensuring the appropriate thermal conditions for employees, animals or technology, high efficiency of installations, reliable operation, modern software and automatic control of the heating process, energy-saving solutions with heat recovery and ecological solutions which do not have a negative impact on the natural environment. These solutions allow them to make the right strategic, technological and managerial decisions.

The most popular systems for heating large buildings are air heating systems with the use of air heaters (water, gas, oil, electric) and heating systems with the use of radiant heaters (water, gas, electric). Floor heating and traditional convection heaters could be also used to heat such a buildings. There are a lot of factors influencing the choice of heating system for a large building [5-7]. It is not clear which of the above systems is better because each investment should be considered individually, taking into account the investor's requirements and design possibilities, with an aim of obtaining rational project costs related to heating, appropriate thermal conditions and safe use.

In general, it can be assumed that if the production hall, in which the technology does not adversely affect the working area, is not built up with high storage racks and there is no requirement for intensive ventilation due to the production type, then the best solution will be heating with gas heaters. If a significant part of the hall is covered with high storage racks (e.g. distribution center) or there is a risk of fire or explosion, or there is a requirement for increased ventilation, then air heaters will be used. If a large part of the hall is used for storage with racks and a large part of the hall is used for unloading and loading of goods, combined systems can be used, i.e. gas air heaters in the high storage part and gas radiant heaters in the cargo area. Infrared radiant heating is also popular in breeding of young animals in industrial conditions [8].

\subsubsection{Gas radiant heating}

Gas infrared heaters are subdivided due to the way of gas/air mixture combustion (on ceramic plate/in tube) and the way of flue gases discharge (into the room/outside the room). Directive 2009/125/EC of the European Parliament and of the Council with regard to ecodesign requirements for local space heaters sets out new definitions of commercial local space heater: luminous local space heater and tube local space heater. The new requirements consistent with ErP (Energy related Products) determine that for luminous local space heater seasonal space heating energy efficiency $\eta_{s}$ has to be greater than $85 \%$, and tube local space heaters need to have energy efficiency greater than 74\% [7].

In design process of infrared heating (on the basis of the heat load determined according to the standard PN-EN 1283) it is crucial to take into account technical parameter radiant efficiency. The radiant efficiency is determined according to the standard EN 419-2 for luminous radiant heaters and according to the standard EN 416-2 for tube radiant heaters. These examinations are made in several laboratories in Europe and, so far, they are not run in Poland. Many manufacturers of radiant heaters specify only their thermal efficiency in their data sheets. It is not the sufficient parameter for selecting the installed capacity and number of heaters. Convection heat, deliver to hall space, is kept under the ceiling of the hall and is treated as lost heat. The radiation efficiency of radiant heaters $\eta_{R}$ is influenced by the quality of materials used for the construction of the reflector and its insulation, the construction of the burner and the shape of the flame inside the radiating pipes. High-performance tube heaters can achieve a radiant efficiency of up to $72 \%$ and high-performance ceramic heaters up to $80 \%$. The thermal efficiency given in the data 
sheets of the gas heaters at the level of $95 \%$ is in fact the efficiency of the burners. By investing in a high-efficiency gas heater system in comparison to radiant heaters of typical designs and lower efficiency, one can save up to $35 \%$ of heating costs [9]. Obviously, more energy efficient heaters are more expensive and in order to assess their profitability, it is necessary to carry out at least an economic analysis. For example, an analysis using radiant heaters of different efficiency proved that a system equipped with the most expensive high-performance radiant heaters gives the lowest cumulative costs after 5 years [9].

\section{Heat recovery systems}

Modern technological solutions enable the recovery of waste heat from flue gases of gas heaters. Thanks to a wide range of different heat exchanger types such as flue gases/air (HEXA) or flue gas/water (HEXW) and heat transport medium, the recovered energy can be used, depending on the needs of the building, for various purposes [4, 10-16].

The flue gas temperature at the outlet from the tube heater depends on the type and efficiency of the heater. For high-efficiency tube heaters $\left(\eta_{\mathrm{R}}=72 \%\right)$, it is almost $200^{\circ} \mathrm{C}$, while for heaters with lower efficiency $\left(\eta_{R}=52-59 \%\right)$, it is about $350^{\circ} \mathrm{C}$. The surface temperature of a bright radiant ceramic plate can be up to $1200^{\circ} \mathrm{C}[6,7]$.

\subsection{Flue gases/water heat exchanger HEXW}

In Fig. 2 the exemplary applied of flue gases/water heat exchanger HEXW is shown [15]. Flue gases discharged by insulated pipes are delivered to heat recovery exchanger by the fan installed at the exchanger. This heat exchanger heats up the water. The temperature of water collected in the tank may reach up to $90^{\circ} \mathrm{C}$. Flue gases are discharged via chimney outside the building. The recovered heat, accumulated in water in the buffer tank, could be further applied for instance for space heating of office rooms.

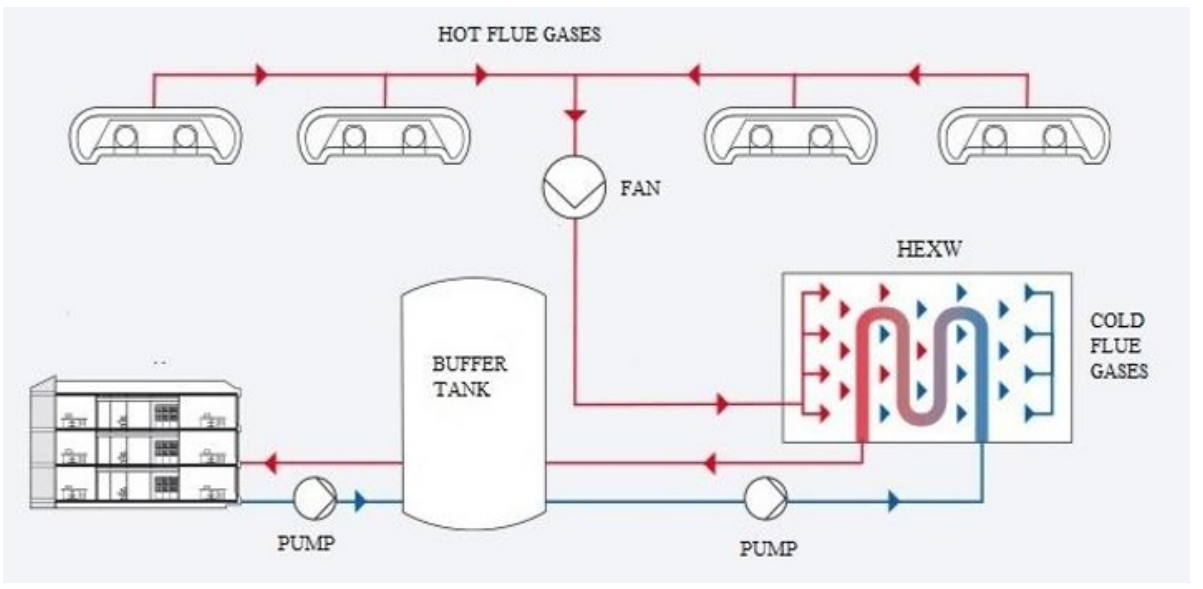

Fig. 2. The exemplary heat recovery system with flue gases/water heat exchanger HEXW for group of gas tube heaters [15].

The other solution is the system adaptation to produce hot tap water. In this case, the buffer tank is replaced by capacity water heater with two coils because the heating system is used in heating season only. The amount of recovered energy from flue gases of radiant heaters depends on the heat demand of the production hall. More heat can be gained during 
colder days than during warmer ones. Hence, such a solution needs additional heat source to produce hot tap water outside the heating season and in case of energy shortage from the waste source. Renewable energy gained e.g. from solar collectors could be a good additional source and allows to create hybrid solutions to hot water preparation. However it is very important to know, that to optimize the energy costs of hot tap water preparation with implementation of renewables and waste sources, the acquisition of knowledge about the amount of water and profile of water consumption and irregularity of water consumption is necessary [17-20].

\subsection{Flue gases/air heat exchanger HEXA}

The use of a flue gases/air heat exchanger heats up the supplied air to the occupied zone for humans and animals. This innovative solution is especially interesting as it can be used in halls heated by both tube and ceramic heaters. The heat recovery system for radiant tube heaters can be made for a single unit or on a collective flue pipe for a group of radiant heaters.

\subsubsection{Recovery system for single gas tube heater}

In this system, the heat exchanger is $4 \mathrm{~m}$ long steel pipe, in which the flue gases are cooled to a dew point temperature (below $57^{\circ} \mathrm{C}$ ) and the condensation of water vapour occurs at counterflow air/flue gases. The heated air is supplied to the occupancy zone by a fan, usually mounted on the cold side of the exchanger. The scheme and photo of the system is shown in Fig. 3 [16]. The capacity limitation of the heater is a result of the large size (over $9 \mathrm{~m}$ in length) of devices with a capacity greater than $40 \mathrm{~kW}$ and very high pressure drops at the flue gases flow. The burners would not be able to cover the pressure losses of the unit and the heat exchanger. The heat recovery system is built individually for each heater. The heaters are not connected into a single exhaust system. The heat exchanger is mounted on the extension of the heater, in a straight line or parallel to the heater. Parallel placement of the radiant heaters and heat exchanger simplifies the discharge of flue gases through the concentric duct and the supply of heated air from outside. The recirculating air temperature during flow through the exchanger increases by approximately $15 \mathrm{~K}[6,16]$.

As a result of the application of flue gases heat recovery and condensation, the thermal efficiency of the system is increased up to $110 \%$ (in reference to the net calorific value). Heat recovery efficiency is estimated at $15-20 \%$, e.g. for $40 \mathrm{~kW}$ radiator up to $6-8 \mathrm{~kW}$ of heat can be recovered. Higher heat recovery efficiency is achieved when colder external air is supplied to the exchanger than when recirculating air from inside the hall is supplied. It is possible to solve the system in two different methods $[6,16]$ :

1 - internal circulating air is supplied to the exchanger; with a concentric chimney external air is supplied to the heater for gas combustion and flue gases are discharged; in this case one hole for each heater is made in the roof oh hall;

2 - with a concentric chimney external air is supplied to the heat exchanger and flue gases are discharged; with a separate duct, external air is supplied to the burner of the heater for gas combustion; in the roof two holes are made for each heater.

The condensate from the exchanger, for example about $25 \mathrm{l} / \mathrm{h}$ for $40 \mathrm{~kW}$ radiant heatres, is collected through plastic pipes with a diameter of $18 \mathrm{~mm}$ and drained gravitationally through a neutralizer to the sewage system. The pipe must be connected by a water siphon. 

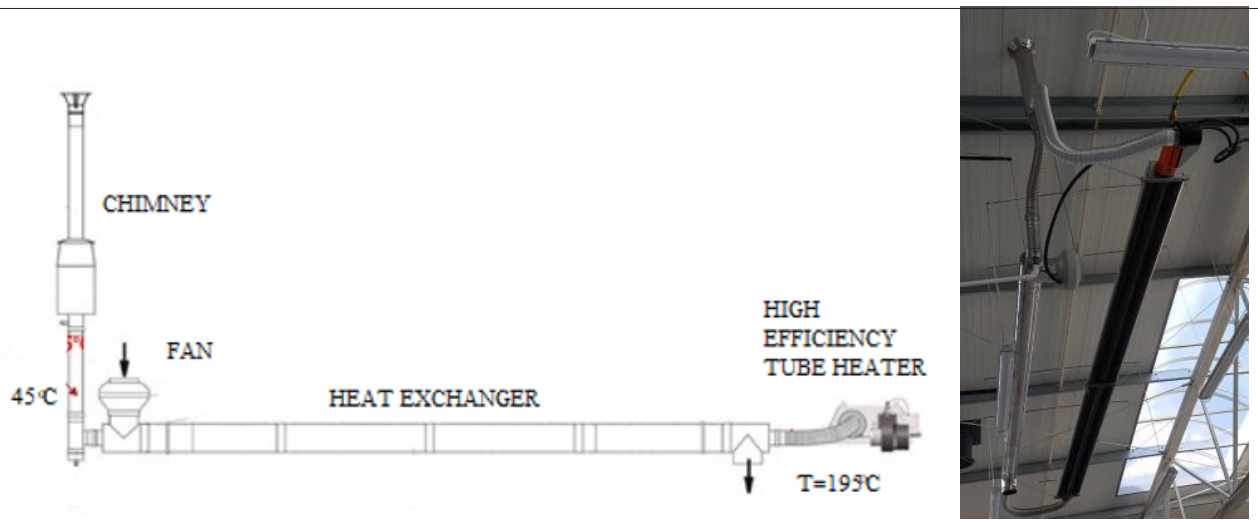

Fig. 3. Scheme and photo of the recovery system for single tube heater [6].

\subsubsection{Recovery system for group of gas tube heaters}

The system shown in Figure 4 can be made for a single heater or for a group of devices with a maximum capacity of $225 \mathrm{~kW}$ [15]. The use of a heat exchanger distant from heaters allows to heat low zones of the hall, where the use of a radiant heater is not possible due to safety reasons, and the use of an additional heating system would be difficult and expensive. The producer of the system reports that such a solution allows to recover $15 \%$ of energy [15].

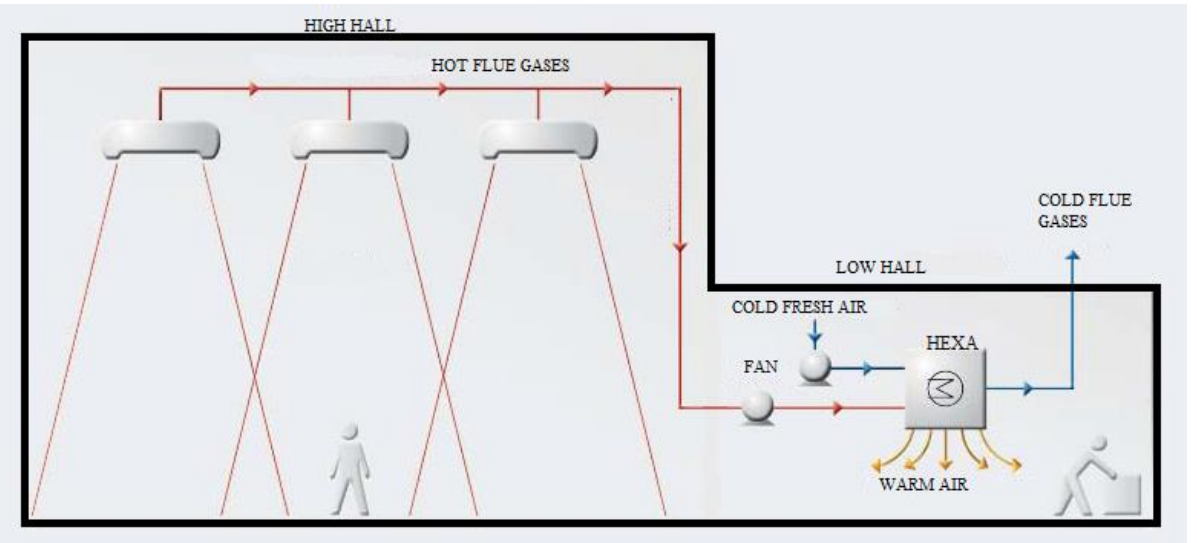

Fig. 4. The exemplary recovery system with flue gases/air heat exchanger HEXA for group of gas tube heaters [15].

\subsubsection{Recovery system for gas ceramic heaters}

The solution of a heat recovery system for ceramic radiant heaters is similar to the system shown in Figure 4. However, flue gases discharge into the room are kept under the ceiling of the hall. Warm air from space under the ceiling is transported by ventilation ducts to the heat exchanger. In the heat exchanger, heat is recovered from waste gases from ceramic gas heaters and from the waste heat of processes carried out in the hall - heat from lighting, 
machinery, technological processes [16]. In the exchanger occurs heat recovery from the extracted air and heating of the external air supplied to the hall. The heated air is directed to the occupancy zone. The producer specifies in the data sheets the efficiency of such exchanger $25 \%$ [16].

\subsection{Comparison of heat recovery systems}

Table 2 summarises the efficiency and features of the above mentioned heat recovery systems used in flue gas discharge systems of radiant heaters. The characteristics of these systems depend on the medium (water or air). They differ in the type of gas heater and the number of radiant heaters collected into the system.

Table 2. Heat recovery systems, efficiency and features.

\begin{tabular}{|c|c|c|}
\hline System of heat recovery & Efficiency & Features \\
\hline $\begin{array}{c}\text { Flue gases/water HEXW: } \\
\text { - group of tube heaters }\end{array}$ & $15 \%$ & $\begin{array}{c}\text { Heat is used to hot tap water preparation or } \\
\text { convection heating; HEXW next to radiant heaters }\end{array}$ \\
\hline $\begin{array}{c}\text { Flue gases/air HEXA: } \\
\text { - single tube heater }\end{array}$ & $15-20 \%$ & $\begin{array}{c}\text { Heating indoor air in the hall } \\
\text { Non-extended system, HEXA next to heaters } \\
\text { - group of tube heaters } \\
\text { - ceramic heaters }\end{array}$ \\
$15 \%$ & $25 \%$ & $\begin{array}{c}\text { Additional heat recovering from light, } \\
\text { technological processes, HEXA in distance }\end{array}$ \\
\hline
\end{tabular}

\subsection{Economic assessment}

The investment in heat recovery from the flue gas heaters may be $35-70 \%$ of the total investment in the hall heating system $[6,19]$. The investment costs of radiant heating are also influenced by the gas installation and its components [21]. The higher the efficiency of heat recovery and heat consumption, the more profitable the investment is.

Each investment requires a detailed energy and economic analysis because of a number of factors to be taken into account. Attention should be paid to the price of the gas fuel in a particular region. Gas prices for consumers in Poland shall be officially approved by the President of the Energy Regulatory Office. However, distributors may offer discounts on tariff prices. This means that significant benefits resulting from a change of gas supplier can be achieved. There are currently 8 main gas distributors in Poland. It is possible to find an offer that is $5-10 \%$ lower than the official price. For a hall where heating costs are a significant part of the operating costs, savings of $10 \%$ are very important.

\section{Conclusion and directions for future research}

Many factors influence on the choice of heating system in a large-cubage building. The choice of a solution should also consider the possibility of heat recovery because exhaust gas heat recovery can highly reduce the energy consumption as well as pollution level.

Reducing energy demand in large-cubage halls is required due to EU regulations and high operating costs. Despite numerous research of heat exchangers, there is very limited number of models focus on their application in flue gases discharge system. Particularly, there is a lack of research on advantages, disadvantages and construction of heat exchanger applied in flue gases system of gas radiant heaters. Findings from literature review and manufacturers solutions shown that there are not too much of heat recovery solutions in the market nowadays. Probably they are not popular because of their application price. 
Characteristic of the heat recovery systems depend on type of gas heaters and differs with medium and number of gas heaters collected to system. This paper proposes new/own classifications according to the medium: flue gases and water HEXW or flue gases and air HEXA. The systems differ in number of radiant heaters collected in the system (single/group), their type (ceramic/tube) and their mounting location (next to/in distance of radiant heaters).

More research is recommended in field of heat recovery from ceramic gas heaters e.g. in place of their mounting or with water as a medium. Energy and profitability analyses should take into account not only the energy gain of the heat recovery system but also the additional energy consumption associated with its operation, e.g. additional electricity consumption to drive a fan, the efficiency of the recovered heat transfer depending on the location of the heat recovery exchanger.

The work was partially financed by The Faculty of Environmental Engineering, Wroclaw University of Science and Technology, Poland no 0401/0055/18. The authors would like to thank the Dean of the Faculty of Environmental Engineering of the Wrocław University of Science and Technology for financing the measurement equipment for future research in this field.

\section{References}

1. Financing of buildings' energy efficiency improvement in Poland (in Polish) (BPIE, Warszawa, 2016)

2. https://nowoczesnehale.elamed.pl [acess 28.02.2019]

3. M. A.Sayegh, J. Danielewicz, T. Nannou, M. Miniewicz, P. Jadwiszczak, K. Piekarska, H. Jouhara, Renew. Sustain. Energy Rev. 68, 1183-1192 (2016)

4. H. Jaber, M. Khaled, T. Lemenand, AIP Conference Proceedings, 1758 (2016)

5. I. Sarbu, A. Tokar, Intern. J. Advanced and Applied Sciences, 3 (2018)

6. E. Dudkiewicz, Rynek Instalacyjny, 12 (2016)

7. E. Dudkiewicz, E3S, 44 (2018)

8. N. Spodyniuk, V. Zhelykh, O. Dzeryn, FME Trans. 46, 651-657 (2018)

9. E. Dudkiewicz, N. Fidorów, J. Jeżowiecki, Rocznik Ochrona Środowiska, 15 (2013)

10. M. Hatami, D. D. Ganji, M. Gorji-Bandpy, Renew. Sustain. Energy Rev. 37 (2014)

11. F. Huang, J. Zheng, J. M. Baleynaud, J. Lu, J. Energy Inst. 90, 951-961 (2017)

12. C. Wang, B. He, S. Sun, Y. Wu, N. Yan, L. Yan, X. Pei, Energy 48, 196-202 (2012)

13. A. Mardiana-Idayu, S. B. Riffat, Renew. Sustain. Energy Rev. 16 (2012)

14. P. Szulc, P. Rączka, K. Wójs, Archiwum Energetyki 1-2, 11-30 (2013)

15. O.p.u.s. x. KÜBLER (2018)

16. http://www.schwank.co.uk/en/home.html

17. L. Liu, L. Fu, Y. Jiang, Energy 35, 1476-1481 (2010)

18. A. Lomet, F. Suard, D. Chèze, Energy Procedia 70, 379-387 (2015)

19. N. Fidorów-Kaprawy, E. Dudkiewicz, Energy 127, 198-208 (2017)

20. E. Dudkiewicz, M. Laska, E3S (to be published)

21. P. Jadwiszczak, W. Cepiński, Rynek Instalacyjny, 12 (2015) 